هUCLM

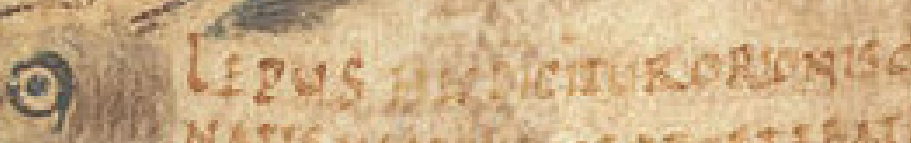

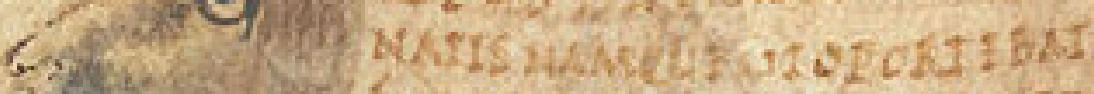
Ediciones de la Universidad

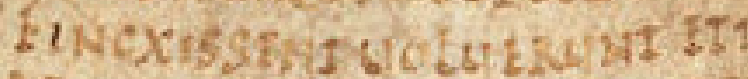

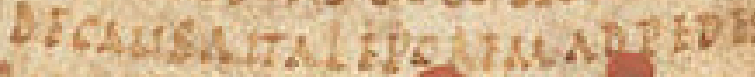

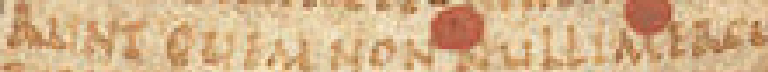

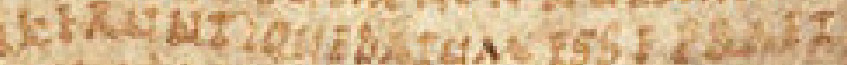

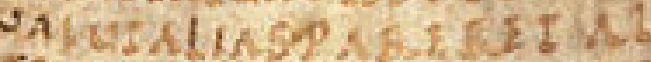

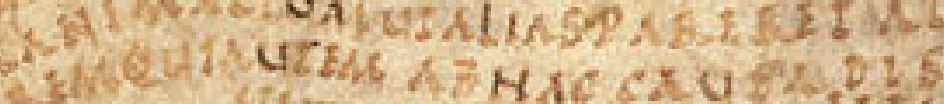
9.

16 tos $b_{2}^{2}-4$

\title{
Estudios lingüísticos de jóvenes investigadores
}

Pilar Morales Herrera

Pilar Peinado Expósito

Yoana Ponsoda Alcázar (Coord.)

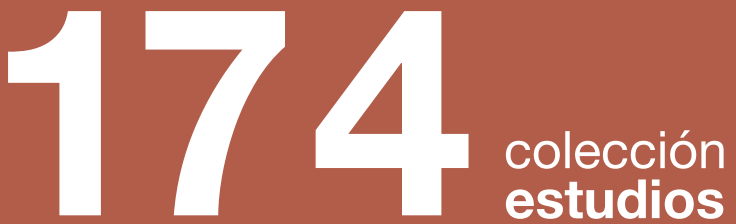





\section{ESTUDIOS LINGÜÍSTICOS DE JÓVENES INVESTIGADORES}





\section{ESTUDIOS LINGÜÍSTICOS DE JÓVENES INVESTIGADORES}

Coordinadoras:

Pilar Morales Herrera

Pilar Peinado Expósito

Yoana Ponsoda Alcázar

Ediciones de la Universidad

Cuenca, 2021 
(C) de los textos e ilustraciones: sus autores.

(C) de la edición: Universidad de Castilla-La Mancha.

Edita: Ediciones de la Universidad de Castilla-La Mancha

Colección ESTUDIOS n. ${ }^{\circ} 174$

Materia: Lingüística histórica y comparada.

Thema: CFF

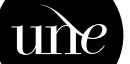

UNIÓN DE

Este libro ha sido sometido a evaluación externa y aprobado por la Comisión de Publicaciones de acuerdo con el Reglamento del Servicio de Publicaciones de la Universidad de Castilla-La Mancha.

ISSN: $2255-2618$

I.S.B.N.: $978-84-9044-482-5$

D.O.I.: http://doi.org/10.18239/estudios_2021.174.00

Composición: Compobell

Hecho en España (U.E.) - Made in Spain (E.U.)

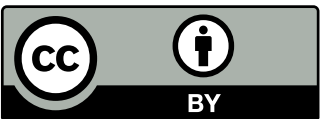

Esta obra se encuentra bajo una licencia internacional Creative Commons CC BY 4.0.

Cualquier forma de reproducción, distribución, comunicación pública o transformación de esta obra no incluida en la licencia Creative Commons CC BY 4.0 solo puede ser realizada con la autorización expresa de los titulares, salvo excepción prevista por la ley. Puede Vd. acceder al texto completo de la licencia en este enlace: https://creativecommons.org/licenses/ by $/ 4.0 /$ deed.es 


\section{COMITÉ CIENTÍFICO}

Carme Bach Martorell

(Universitat Pompeu Fabra)

María Jesús Barros García

(Northwestern University)

Carlota de Benito Moreno

(University of Zurich)

Bruno Camus Bergareche

(Universidad de Castilla-La Mancha)

Ángeles Carrasco Gutiérrez

(Universidad de Castilla-La Mancha)

Nicole Delbecque

(Katholieke Universiteit Leuven)

Antonio Fábregas

(Universitetet i Tromsø)

Raquel Fornieles Sánchez

(Universidad Autónoma de Madrid)

Mar Garachana Camarero

(Universidad Autónoma de Barcelona)

Fernando García Andreva

(Universidad de La Rioja)

José María García Martín

(Universidad de Cádiz)

Sara Gómez Seibane

(Universidad de La Rioja)

Jacinto González Cobas

(Universidad Autónoma de Madrid)

Edita Gutiérrez Rodríguez

(Universidad Complutense de Madrid)

Silvia Gumiel Molina

(Universidad de Alcalá de Henares)

M. a del Carmen Horno Chéliz

(Universidad de Zaragoza)

Brenda Laca Luque

(Universidad de la República)
Alicia Mellado Prado

(Investigadora independiente)

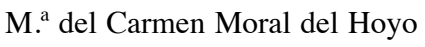

(Universidad de Cantabria)

Aroa Orrequia Barea

(Universidad de Jaén)

Pilar Pérez Ocón

(Universidad de Alcalá de Henares)

Rogelio Ponce de León Romeo

(Universidade do Porto)

Margarita Porroche Ballesteros

(Universidad de Zaragoza)

Santiago del Rey Quesada

(Universidad de Sevilla)

Graça Rio-Torto

(Universidade de Coimbra)

José Javier Rodríguez Toro

(Universidad de Sevilla)

Ángeles Romero Cambrón

(Universidad de Castilla-La Mancha)

Begoña Sanromán Vilas

(University of Helsinki)

Ana Serradilla Castaño

(Universidad Autónoma de Madrid)

David Serrano Dolader

(Universidad de Zaragoza)

María Jesús Torrens Álvarez (ILLA-CSIC)

Alina Villalva

(Universidade de Lisboa)

Margot Vivanco Gefaell

Universidad de Castilla-La Mancha) 



\section{ÍNDICE}

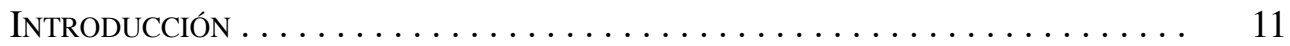

CAPítUlo 1. Estudios de FONÉTICA, GRAMÁTICA y PRAGMÁtiCA $\ldots \ldots \ldots \ldots$

Testing the role of language familiarity in aural perceptual recognition: a pilot study . . . . . . . . . . . . . . . . . . . . . . . .

José Vicente Benavent Cháfer

Estrategias pragmáticas de atenuación empleadas en rechazos a invitaciones y propuestas en mensajes de WhatsApp de adolescentes .............. Àngela Magraner Mifsud

Ser posible/probable que + indicativo. El uso inesperado del indicativo con los predicados de posibilidad y de probabilidad ................. Bora Choi

Algunas notas sobre el modo de acción de los verbos psicológicos reflexivos Pilar Morales Herrera

El uso pseudo-copulativo del verbo salir: coacción y reinterpretación ...... Linghan Xiong

CAPítulo 2. SociolingüísticA $\ldots \ldots \ldots \ldots \ldots \ldots \ldots \ldots \ldots \ldots \ldots \ldots$

Speaker legitimacy in contexts of minority language revitalization: a case study of attitudinal responses towards varieties of basque ............

Karolin Breda 
Variación sociolingüística y morfosintáctica: actitudes lingüísticas en el español de La Mancha . . . . . . . . . . . . . . . . . . . . . . . . . . . . . . . . . . . . .

Pilar Peinado Expósito

Shaping sociolinguistic practices in congo-brazzaville Jean Mathieu Tsoumou

CAPítulo 3. Historia de LA LeNGUA y estudios CLÁSicos $\ldots \ldots \ldots \ldots \ldots$

Algunos problemas sobre el cambio de la F latina desde el punto de vista de la lingüística románica

Yohei Mishima

Contribución al estudio de los usos de la puntuación en la General estoria . . Miguel Las Heras Calvo

Distribución de las formas posesivas de tercera persona en el castellano medieval de los siglos XII-XIII

Yoana Ponsoda Alcázar

La verdad es hija del tiempo: un recorrido histórico por las denominaciones de la verdad en español.

Ana María Romera Manzanares

Explotación sociolingüística del Léxico de Hesiquio

Sandra Pérez Ródenas

CAPítulo 4. ENSEÑANZA DEL ESPAÑOL Y OTROS IDiOMAS COMO LENGUA

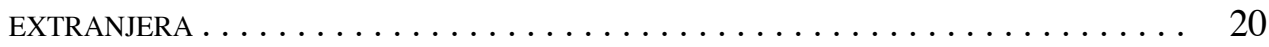

Didáctica de las preposiciones desde un enfoque semántico-cognitivo . . . . 203 Jordina Frago Cañellas

El cortometraje como recurso didáctico en el aula de ELE/L2 para enseñar el español oral coloquial a estudiantes erasmus

Alba Rodrigo Martín de Lucía

Aprendizaje y adquisición de la lengua española para el alumnado arabófono: interferencias lingüísticas, pragmáticas y culturales..............

Rosa Salgado Suárez

La variación lingüística en la literatura sobre la enseñanza/aprendizaje del portugués brasileño .

Miley Antonia Almeida Guimarães 


\title{
SHAPING SOCIOLINGUISTIC PRACTICES IN CONGO-BRAZZAVILLE
}

\author{
JEAN MATHIEU TSOUMOU \\ Universidad Europea de Canarias
}

\section{INTRODUCTION}

The present paper is divided into three sections and aims at drawing the linguistic picture across Congo-Brazzaville as well as shedding light on the multilingual issues governing the sociolinguistic environment. The first section presents the linguistic situation in Congo, with emphasis on the different linguistic functions displayed by languages as well as their typical linguistic features. Attention is devoted to the rise and evolution of Kituba and Lingala which are both major and widespread indigenous lingua francas in Congo-Brazzaville. Section two describes the conditions under which French, the current official language, was elected and implemented. Finally, section three examines potential patterns of multilingualism across the country by broadening both the use of lingua francas and patterns of language use.

\subsection{Languages in congo-brazzaville ${ }^{1}$}

The linguistic situation in Congo is complex. Such complexity lies both in the co-existence and interplay of its several languages. About sixty indigenous lan-

1 Congo-Brazzaville is one of the eleven countries that make up the Community of Central African States (CCAS). It is also one of the six-member states of the CEMAC (The Central African Economic and Monetary Community). Bordered by five neighbouring countries - Cameroon to the 
guages are spoken within the national borders, with French being the only national official language. There is a clear difficulty in determining the precise number of languages in Congo.

Firstly, linguists always face uncertainty in adequately defining the term "langua$g e$ " as opposed to "dialect". The traditional criterion of mutual intelligibility is now questionable (Myers-Scotton 2006; Ogechi 2003; McWhorter 2016). Evidence proves that two dialects of the same language may become two distinct languages based on political, social and economic considerations. A notable example is the case of Norwegian, Swedish and Danish, which are all considered separate languages while systematically forming three dialects among which mutual intelligibility is observable (Auer 1984a; Appel \& Muysken 1987; Myers-Scotton 1993a; Ogechi 2003; McWhorter 2016). History, culture, politics and economics are fundamental factors accounting for the distinction between language and dialect. Another substantial example can be found in Uganda, where Myers-Scotton (1993a: 9) explains that "although they are mutually intelligible, Acholi and Lango are called separate languages, probably because the people see themselves as having different histories". A similar case holds for many languages such as Kaamba versus Laari and Suundi versus Vili in CongoBrazzaville. Kaamba and Laari are mutually understandable. Speakers converse with each other in their own native tongues. Linguists usually name these dialects of Koongo (Ndamba 2000; Mamono 2012; Ngoko 2013). However, because of history and political controversy, Kaamba or Laari native speakers might be tempted to think of themselves as native speakers of separate languages.

Secondly, in 1960 Congo-Brazzaville was declared independent from France, and the French language ultimately became the sole national official language. During the first-ever National Conference in 1991 Kituba and Lingala both received subsidiary official recognition and became the national vehicle languages. No official attribution was ascribed to the remaining national languages, which have ever since been reduced to simple dialects.

Regarding the typology of languages spoken in Congo-Brazzaville, the scholarly literature shows that, given their origins, the languages spoken within the national borders derive from two linguistic sources; Bantu-based and Ubangian-based languages (Guthrie 1971; Mufwene 2009; Samarin 1991a, 1991b, 2013).

Bantu languages spoken in Congo-Brazzaville are often divided into four groups which include Group Koongo (H10), Group Téké (B70), Group Mbochi (C20),

Northwest, the Central African Republic to the Northeast, Gabon to the West, the Democratic Republic of Congo to the East and South, and Angolan exclave of Cabinda to the Southwest - CongoBrazzaville accounts for a population of over 5 million, a vast majority of whom lives in Brazzaville and Pointe-Noire, the two largest towns. 
Group Njem (A80). Firstly, Group Koongo (H10) includes languages such as Beembe, Doondo, Gaangala, Kaamba, Suundi, Laari, among many others, spoken in the Southwest of Congo, particularly in the regions of Kouilou, Niari, Lekoumou, Buenza, and Brazzaville. Secondly, Group Téké (B70) includes languages such as Boo, Fuumu, Kukua, Ngunguwel, Téké-Alima, and so on, mostly spoken in South and Central Congo, especially in the regions of Plateaux, Cuvette. Thirdly, Group Mbochi (C20) includes languages such as Akwa, Koyo, Kwala, Mbochi-Bunji, Mbochi-Ole and many others spoken in the upper Northern part of the country. Finally, Group Njem (A80) includes languages such as Bekwel, Mpyemo, Mwaly, Njem and others found in the extreme North of Congo, in the Regions of Likouala, Sangha, and Ouesso (Baka 2005).

With regard to the Ubangian-based languages, they represent a very small group, mainly spoken in the Regions of Sangha, Likouala, Ouesso Impfondo. They include languages such as Baka, Banja, Gbaka, and Gbaya.

\subsubsection{Systematic features of bantu languages}

Bantu languages are governed by at least four major systematic features: Noun Class System, Agglutination, Reduplication, and Tonal system (Demuth 2000, 2001). Such patterns are complex as they affect the whole grammar and morphosyntactic features in most Bantu languages.

To begin with, as defined in SIL Glossary of Linguistic terms ${ }^{2}$, a noun class system is a grammatical system that some languages - Bantu languages in the present case - use overtly to categorise nouns. Noun classes are (1) often based, at least in part, on characteristics (such as gender, animacy, shape and so on) of the referent of some of the nouns in each class, and (2) distinguished by an affix on the noun or word in the noun phrase, and an agreement of affixes on noun phrase constituents and on the verb. The noun class system is thus a substantial systematic characteristic of Bantu languages that describes the morphosyntactic system since these classes realise as grammatical morphemes rather than independent items (Demuth 2000). Myers-Scotton points out that

a prominent feature of Bantu languages is their noun class system. [...] most languages have about 18 noun classes, but up to 22 are posited for proto-Bantu. Nouns are marked according to class membership by the prefixes they receive, as well as the agreement they govern on their modifiers, and their pro-forms occurring as obligatory subject prefixes in verbal assemblies and, also as object prefixes in these assemblies (1993a: 10).

2 http://www.glossary.sil.org/term/noun-class Retrieved on August 17th 2017 
In the second place, most Bantu languages are genetically agglutinative, which means that some of their words are made up of a linear sequence of distinct morphemes and each component of meaning is represented by its own morpheme ${ }^{3}$. In other words, Bantu languages more often tend to express concepts in complex words consisting of many linguistic elements (Cf. Example $1 \& 2$ below). For example, prefixes are ultimate grammatical elements that indicate noun classes in Bantu languages. The relationship between prefixes and nouns constitutes a pivotal agreement whereby a form of a noun requires a corresponding form of a prefix (Ndouli 2001; Ikemou 2010; Apondza-Gombe 2010; Mamono-Ngolo 2012; Ngoko 2013). As shown in example 1, the prefixes mo- and ba- function as an agreement marker on the quantitative roots in Lingala.

(1) (from the Lingala language)
a. Moto moko
"a person"
b. Bato babale
"two persons"

Moreover, reduplication is an additional main characteristic of the morphosyntactic system of some Bantu languages. Reduplication is usually defined as a morphological process in which the root or a stem of a word is repeated exactly or with a slight change in order to convey some grammatical and/or semantic functions. In other words, some words in most Bantu languages are meaningfully created on the basis of replicating one word just as described in example 2 below. Reduplication is also an indicator of the frequency and the intensity of the action signalled by the verb stem.

(2) (From the Lingala language)

a. Noki

"soon"

b. Noki noki

"emergency"

To conclude, tones are also a basic characteristic of Bantu languages. The Oxford Dictionary of English ${ }^{4}$ defines tone as a particular pitch pattern on a syllable used to make semantic distinction. In Lingala, for instance, [Mòtò] means "a person", but if the tone changes to [Mòtó] the meaning is "head", and if it changes to [Mótò] it means "a fire or light".

3 http://www.glossary.sil.org/term/agglutinative-language. Retrieved on August 17 ${ }^{\text {th }}, 2017$

4 Oxford Dictionary of English ( $3^{\text {rd }}$ ed.) 


\subsubsection{The rise of kituba}

Kituba is a contact-based language which arose under some historical circumstances at the end of the $19^{\text {th }}$ century due to some potential needs of a lingua franca in the Southeast of Congo-Braazzaville.

There seems to have been a widespread view that the French settlers who first arrived in Congo-Brazzaville came by boats sailing along the Pointe-Noire coast (Samarin 1991a, 1991b, 2013; Ndamba 2008; Mufwene 2009). Pointe-Noire then soon became the first attractive centre where slaves were sold, bought and deported. Assumingly, this implies that there may progressively have appeared a potential need of a means of communication among people then circumstantially gathered together (traders and indigenes). Hence this interpretation supposes that at first French settlers may have spoken an oversimplified, pidgin form of French to which indigenous people attempted to accommodate their different local languages or vice versa. The main objective of this would have been to establish and facilitate communication, and as such a contact (between French settlers and missionaries and indigenous people) may have favoured the rise of a pidginized form that later became Kituba. Samarin's (1991a: 6) argument is convincing as he indicates that "it [Kituba] arose out of a widely known language that was not, however, true lingua franca; it arose out of somewhat pidginised lingua franca, and that it was created as pidginized lingua franca at the time of colonization".

Additionally, in the late $19^{\text {th }}$ and the early $20^{\text {th }}$ centuries many West Africans arrived in Pointe-Noire, settling in along the coast as the environment there started to offer several opportunities for living. In such a multilingual and/or multicultural environment Kituba appeared the best choice to meet the needs of the time. More importantly, in the 1920s the construction of the first railway between Pointe-Noire and Brazzaville started. This huge project had to be executed manually and a large workforce was required from overseas as the construction lasted over 11 years, and many thousands of people lost their lives. Kituba was thus spoken at the workplace between workers and settlers as well as among workers as they came from different linguistic backgrounds. Mufwene (2009: 1) explains that "like Lingala, Kituba evolved mostly out of labour migrations occasioned in the case by the construction of the railway connecting Kinshasa to the Atlantic Ocean in the early 20th century."

Kituba is spoken not only in Congo-Brazzaville but it is also used in the Southwestern part of the Democratic Republic of Congo and in the Northern part of Angola. It still serves as both a lingua franca ${ }^{5}$ and a first language of most youngsters born in towns such as Brazzaville, Pointe Noire (Congo-Brazzaville),

5 Lingua franca is thereby defined as a common language used by people of diverse backgrounds. 
and Kinshasa, Kisangani (in the Democratic Republic of Congo). Mufwene (2009: 217) indicates that "while the young urban population generally speaks it as their mother tongue, a good proportion of the urban adult population still uses Kituba as a second or third language, although the overwhelming majority of them are fluent speakers".

However, Kituba has been classified as a Bantu language (Guthrie 1971), though it still does not fully present the same typical linguistic features as many other Bantu languages do. As pointed out by Mufwene (ibid), Kituba's structures are often different from those of the varieties globally referred to as ethnic Kikongo. One notable example is that ethnic Kikongo varieties have a lexical and grammatical tone, whereas Kituba has a predominantly fixed accent system, with the accent on the penultimate syllable.

\subsubsection{The rise of lingala}

Unlike Kituba which spread in the Southwest, Lingala arose in the area around the Congo River, in the Northwest of Congo, halfway between the Democratic Republic of Congo and Congo-Brazzaville. Most attempts at an explanation regarding its origin conclude that Lingala emerged among the tradesmen and riverine people of the Mongala, Ngiri, and Ubangui rivers who sailed these rivers in wooden canoes, known as bwato in Lingala, before and after their colonisation, in order to sell their agricultural and fishing produce (Motingea Mangulu and Mwamakasa 2008; Mufwene 2009; Yocum 2014). Yocum points out that

although there are different explanations of how that language evolved, it is usually agreed that Lingala evolved from Bobangi, the trade language of the Bangala (pl. form of Mongala), a cultural group of living along the Congo River upstream from what is now Kinshasa in the Mid-19th century (2014: 4).

Colonisation seems to have pushed forward Lingala since the settlers had to speak it in order to better impose and settle their domination upon indigenous people, as within the Congo River basin Lingala is practically spoken by inhabitants from both sides of the river as they share almost similar cultures and similar languages. More importantly, Lingala emerged because people from different linguistic backgrounds were gathered together to achieve specific goals. In fact, it could be argued that along the Congo River and adjacent stretches of tributaries Lingala speakers have used a linguistic predecessor, Bobangi, as a means of communication with other river cultures. As traders who travelled the River they had to negotiate with ethnic groups who never spoke other languages. As Kituba, Lingala is a lingua franca. 
Lingala is actually a widespread and overused lingua franca in Congo-Brazzaville. The Lingala linguistic region occupies about half the territory of CongoBrazzaville and covers nearly the entire northern part of the country and much of the West from Brazzaville to Impfondo. Being able to communicate in Lingala is crucial for people living in areas around. Although French is the official language, Lingala is the main language of many inhabitants of all the towns in the North of the country (Samarin 1991a, 1991b, Mufwene 2009; Mwamba Kabasele 2014).

At the structural level Lingala is systematically a typical Bantu-based lingua franca. Basic linguistic features of most Bantu languages are present in Lingala. Fifteen noun classes govern its morphological system. Tones and agglutination are also semantically and grammatically as important elements as noun classes in Lingala as well.

(3).

a.sango
"news"
Sángó
"churchman"
b.Nakangá
"I closed"
Nakanga
"I close"

\subsection{The process of choosing an official language}

As mentioned before, the country became independent in 1960 and French was appointed the official language. Certainly, this choice of French as the sole national official language was predominantly based on political and economic rather than emotional considerations.

On the one hand, in the 1960 s, while French was ascribed such a predominant status, less than ten percent of the average population could speak it fluently (Calvet 1994). On the other hand, unlike other African countries such as Kenya and Mozambique, where there are no indigenous languages numerically dominant (Myers-Scotton 1993a), Kituba and Lingala have always been numerically widespread in Congo. That is, if an official language had to be chosen only by virtue of its relative ethnic neutrality and emotional considerations, both Kituba and Lingala could certainly have been appropriate choices for multiple reasons.

On the one hand, languages have always set up social boundaries as they play a substantial role in the political stability of the nation. Each ethnic group wants to impose its dominance upon others. Political conflicts are also linguistic 
as they often oppose one ethnic group to another. The choice of an official language is indeed subject to political implications. In the second place, Kituba and Lingala have always been neutral communication tools since they are used all over the country with no stereotypes attached. Being lingua francas, no practical social identity lies behind their public or private use. They are often used with no apparent political incidence on their speakers. Furthermore, although it has never been overtly pointed out, the use of French has always remained an explicit indicator of ruthless colonization once endured. Morally this still has negative implications in the way Congolese people regard French as opposed to other national languages. Moreover, it is certainly clear that both Kituba and Lingala were numerically dominant. Unlike French, which is mostly used by educated people, Lingala and Kituba, for example, are understood by almost everyone, regardless of social class (Ndamba 2011). In this respect, promoting either Kituba or Lingala would have been a perfect match that would linguistically include all citizens in the development of the country. To conclude, even though French is the only national official language, it has become apparent that being able to communicate in French is just part of the picture. The reality is that the languages spoken in everyday conversation are Lingala and Kituba. Most Congolese people, for instance in Brazzaville, are relatively fluent in both Kituba and Lingala as they are used at work, in shops and in restaurants. They are frequently heard in a song played on the radio, at church, and in the clubs, to name just a few places. They are both the real languages of most urban people no matter how educated.

French has gained an increasing official recognition in the linguistic configuration of the country since 1960 (Cf. Figure 1 below). It is the compulsory language and a school subject from primary school to university. It has been strongly established in almost all officially major roles in the government, mass media and business spheres.

While real access to French comes through extended formal education, becoming fluent in Kituba and/or Lingala is entirely independent of any formal education. They are spontaneously acquired and usually used with no stereotypical significance. In Kituba, for example, Mufwene indicates that

since its beginning, Kituba has functioned as a lingua franca, especially in the extra-coutumiers non-traditional centers formed by the colonial administration, in the Christian missions, and in the factory towns created by large concession and exploitation companies (2009: 217).

The difference between French and the two local lingua francas is also structural. While Kituba and Lingala are both Bantu-based languages, structurally characteri- 
sed by features such as agglutination and the Noun Class System or reduplication, French is an inflectional language based on the SVO system.

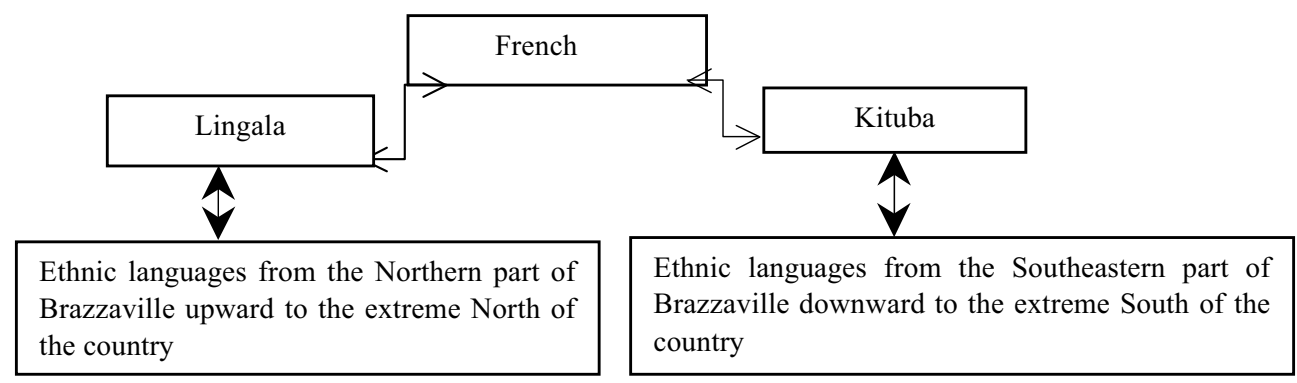

Fig.1: Picture of linguistic practices in Congo-Brazzaville

Kituba and Lingala are both contact based, which means they are not associated with a particular ethnic group. They therefore serve as indigenous lingua francas together with French, which serves as exogenous lingua franca, mainly among educated people. Both languages arose as people from different ethnolinguistic groups were brought to live next to and with each other in such new localities; Lingala from the North and Kituba from the South.

It is essential to note that these two languages have a relatively elaborated grammatical system developed by missionaries and language experts at the department of linguistics at Marien Ngouabi university However, it seems hard to describe the extent to which an average person knows the standard written form of these languages since they are not taught at all in the national educational system. One could argue that an average person who has no linguistic background might spell or write Kituba or Lingala words as they literally hear them.

It is also important to argue that social identities are usually expressed by means of an ethnic language since they represent the L1 for most citizens. An ethnic group is thus named after a corresponding ethnic language, which, in turn, operates as an indication of both social and linguistic identities. Paradoxically, these are not easily accepted, especially in public spheres, since most people cover those by means of avoiding ethnic languages. One of the reasons for this avoidance might be the overrated value attached to the French language. French is a highly rated language whose use suggests high education, and modern-day life; whereas the use of ethnic languages is stereotypically downgraded to that ordinary and lower position in life. In other words, ethnic languages are simply considered negligible and less worthy than their hegemonic or imperial counterparts (Calvet 1994). 


\subsection{Patterns of multilingualism in congo-brazzaville}

In Congo-Brazzaville almost everyone is multilingual (Ndamba 2011; Massoumou 2001, 2003a). In addition to a first language (L1), usually ethnic, the typical urban person may, a priori, have acquired one of the two indigenous lingua francas (Kituba and Lingala as his/her L2) and, later an official language (French as L3). Two factors need to be taken into account in the distribution of multilingualism in Congo-Brazzaville.

The first point to consider is that the typical multilingual situation of an urban person in Congo-Brazzaville is diglossic. According to Ferguson (1959), diglossia is

a relatively stable language situation, in which in addition to the primary dialects of the language, which may include a standard or regional standards, there is a very divergent, highly codified, often grammatically more complex, superposed variety, the vehicle of a large and respected body of written literature, either of an earlier or in another speech community, which is learned largely by formal education and is used for most written and formal spoken purposes but is not used by any sector of the community for ordinary conversation (Ferguson, quoted in Chekayri 2006: 41-2).

Chekayri (2006: 42) supports Ferguson's definition as he believes that Ferguson makes a good distinction between:

a) oral and written registers;

b) two different codes where high $(\mathrm{H})$ refers to the superposed variety and low (L) refers to other varieties;

c) written literature which is learned largely by formal education and other varieties learned outside literacy context; and

d) an $\mathrm{H}$ variety, used for most written and formal spoken purposes, as opposed to an L variety, which is used in informal speech.

The aforementioned interpretation seems to be compatible when applied to the case of Congo-Brazzaville. As regards the first distinction, (a) oral and written registers are ascribed to French, which is both the oral and the written language or register. As for the second aspect, French is a high $(\mathrm{H})$ or a dominant language and refers to the superposed variety whereas Kituba and Lingala (the low (L) languages) refer to the other varieties. In relation to the third point, French is a written variety which is learned largely in formal education and Kituba and Lingala are varieties learned outside the literacy context, and mostly used as spoken varieties. Finally, as for the last distinction, French is the high variety used for most formal spoken purposes, as opposed to Kituba and Lingala, the low varieties, which are used for informal spoken interaction. 
Another point is that education is a key element in shaping the multilingual practices in Congo-Brazzaville. At its basis, extended education means learning the official language (as it is the main medium of education in the entire educational system) in addition to the mother tongue. Educated people are thus highly exposed (or predisposed) to acquiring and/or learning several languages.

\subsubsection{Patterns of language use and the use of lingua francas in congo-brazzaville}

In Congo-Brazzaville people do not only speak a lingua franca as their second language; they also know some other languages (Massoumou 2001 2003a; Ndamba 2000). Learning another ethnic language results in many types of social relationships, e.g. neighbourhood, client-shopkeeper, boss-employee, to name just a few. Even in a relatively remote rural area where almost everyone is a first-language speaker of an ethnic language, people living there undergo the influence of Kituba or Lingala.

In such a multilingual context at least four sets of language use can be identified, especially in urban areas: home, neighbourhood, workplace and school. Unlike rural areas where a single language can be used both with neighbours and within a family, in urban centres each language better operates in a specific context (at home, with neighbours, at work and at school). A notable example could be a university student who is fluent in French and who uses it most of the time at university, and who becomes quite a different person (using different languages) when s/ he goes online to chat, when $\mathrm{s} / \mathrm{he}$ interacts in the streets with friends or neighbours, when s/he goes home to become a father/mother, an uncle/aunt, a brother/sister, etc.

There are languages almost exclusively spoken with family members (mostly ethnic languages), in a neighbouring setting (mostly Kituba and/or Kituba), at school (mostly French), and in the workplace (mostly French). At first, unless descending from an inter-ethnic marriage or from a highly educated couple, Congolese people still speak their mother tongues among family members. Secondly, with neighbours from other ethnic groups there is a need to use a neutral language. Lingua francas like Kituba and Lingala mostly intervene in such situations. Thirdly, with co-workers and online (mostly in formal situations) French is the only language expected to be used. As a result, patterns of CS can be observed in family encounters (between a lingua franca and a mother tongue, or between a mother tongue or any lingua franca and the official language), in the neighbourhood (between any lingua franca and the official language), in the workplace (between any lingua franca and the official language, with the lingua franca usually used in informal interaction) (Ndamba 2011; Massoumou 2003b).

Regarding factors promoting codeswitching, Myers-Scotton (1993a: 39) points out, however, that "how much codeswitching occurs seems to be [or is] a function 
of the speaker's educational level and occupation, but also of age". For example, Congolese people at the top of the socio-economic ladder are those who speak French (the official language) most of the time with children at home to improve their chances to do better at school. They are also aware of how to display language use in different communicative contexts.

\subsection{Conclusion}

This paper has drawn the sociolinguistic configuration across the country. It has then shed light on linguistic practices offline. On the one hand, it was stated that, apart from French, two language families control the linguistic situation in Congo-Brazzaville, namel, Bantu and Ubanguian languages. On the other hand, it was reported that most of the languages spoken in Congo (apart from French) are Bantu-based, mostly characterized by four major features such as Noun Class System, Agglutination, Reduplication, and Tonal system. Furthermore, issues involving language use were discussed and clarified as well as patterns of multilingualism. Finally, particular emphasis was accorded to Lingala, Kituba, and French, which are the three lingua francas widely used across the country. The linguistic features of these languages were presented as well. The present analytical description has set foundations for future research; for example, an investigation of the interplay between the use of languages in off- and online communication would be very encouraging since that study would shed light on the way Congolese people interact in both communicative environments.

\section{BIBLIOGRAPHY}

APONDZA-GOMBE, Guy Roger Cyriac (2010): Les unités de première articulation en akwa de la chanson de Kingoli. Thèse de doctorat. Université Marien Ngouabi de Brazzaville.

Appel, Rene y Muysken, Pieter (1987): Language contact and Bilingualism. Amsterdam University Press.

Auer, Peter (1984a): Bilingual conversation: Pragmatics and Beyond. Parret \& Verschueren.

BAKA, Jean (2005): «Problématique pour une meilleure gestion du multilinguisme social de type Afro-Européen en Afrique au sud du Sahara». Afrika Focus, 18, 95-118.

CALVET, Louis Jean (1994): Les voix de la ville : Introduction à la sociolinguistique urbaine. Petite Bibliothèque Payot. Paris.

CHEKAYRI, Abdellah (2006): «Diglossia or triglossia in Moroco: Reality and Facts». Arabe marroqui: studio, enseñaza y aprendizaje, 1, 41-58. 
Demuth, Katherine (2000): «Bantu noun class systems: Loan word and acquisition evidence of semantic productivity», en Senft Gold. (ed.): Classification Systems, Cambridge University Press, 270-292.

DemUTH, Katherine (2001): «Prosodic constraints on morphological development», en John Weissenborn y Höhle Blair (eds.): Approaches to bootstrapping: Phonological, Syntactic and Neurophysiological aspects of early language acquisition. Amsterdam: John Benjamins, 3-21.

GuTHRIE, Malcolm (1971): Comparative Bantu: an introduction to the comparative linguistics and prehistory of the Bantu languages. Farnborough : Gregg Press.

Ikemou, Regina (2010): Description phonologique du koyo-nganza, parler Bantu du groupe C20. Mémoire de Maîtrise. Université Marien Ngouabi de Brazzaville.

Mamono, Ngolo Gladia (2012): Les Classes nominales du parler etyec B73e (District de Tsiaki, département de la Bouenza-Congo. Mémoire de Maîtrise. Université Marien Ngouabi de Brazzaville.

Massoumou, Omer (2001): «Des usages linguistiques actuels en République du Congo». Cahiers du Rifal. Développement linguistique : enjeux et perspectives, $22,73-78$.

Massoumou, Omer (2003a): «Les usages linguistiques à Brazzaville : La place du Français». Réseau de chercheurs Observation du français et des langues nationales, Agence universitaire de la Francophonie (AUF), 2, 14-28.

Massoumou, Omer (2003b): «Fautes, particularismes et évaluation du Français en République du Congo». Communication aux Etats généraux de l'enseignement du français en Afrique subsaharienne francophone, 17, 88-99.

MCWHORTER, John (2016): «What's a Language, Anyway?». The realities of speech are much more complicated than the words used to describe it, 6, 77-99.

Motingea-Mangulu, Andre y Bonzoi mwamakasa (2008): «Aux sources du Lingála: Cas du mbenga de mankanza - Nouvel Anvers». African Study Monographs, 38, 1-93.

Mufwene, Salikoko (2009): Le nom des langues III. Le nom des langues en Afrique sub-saharienne : pratiques dénominations, catégorisations. Naming Languages in Sub-Saharan Africa: Practices, Names, Categorisations, Louvain-la-Neuve, Peeters, BCILL.

Mwamba-Kabasele, Philothe (2014): Structural transfer in third Language acquisition: The Case of Lingala-French speakers acquiring English. Master's Degree. University of Illinois-Urbana-Champaign.

Myers-SCOTTON, Carol (1993a): Social motivations for codeswitching: Evidence from Africa. Oxford University Press. 
Myers-SCOTTON, Carol (2006): Multiple Voices: An introduction to Bilingualism. Oxford. Blackwell Publishing Ltd.

NDAMBA, Josué (2000): «Des Véhiculaires aux vernaculaires à Brazzaville : la ville et les changements de fonctions linguistiques». Le Plurilinguisme urbain, 17, $135-145$

Ndamba, Josué (2008): «Evaluation dialectométrique des langues et dialectes du département du Kouilou». Revue gabonaise des sciences du langue. 4, 7-25.

Ndamba, Josué (2011): Pour une linguistique du développement en Afrique. Mémoire présenté en vue d'obtenir le diplôme d'Habilitation à Diriger les Recherches. Université de Provence-Marseille.

Ndouli, Guy Blaise (2001): Description phonologique du mbere : parler de Tsama. Mémoire de Maîtrise. Université Marien Ngouabi de Brazzaville.

NgOKo, Arnaud (2013): Les Classes nominales dans le parler ibwiisi du Congo (B45). Mémoire de Maîtrise. Université Marien Ngouabi de Brazzaville.

Nкоuка, Martial (2001): Emergence des langues véhiculaires comme langues maternelles chez les adolescents congolais des arrondissements Bacongo et Ouénzé. Mémoire de Maîtrise. Université Marien Ngouabi de Brazzaville.

OGECHI, Nathan Ooyori (2003): «On language rights in Kenya». Nordic Journal of African Studies, 12, 277-295.

OXFORD DictionARY OF ENGLISH ( $3^{\text {rd }}$ ed.) 2010.

SAMARIN, William (1991a): Official language: The case of Lingala. Toronto (Canada). SAMARIN, William (1991b): «The origins of Kituba and Lingala». Journal of African Languages and Linguistics, 12, 54-67.

SAMARIn, William (2013): «Versions of Kituba's origin: Historiography and theory». JALL, 34(1), 111-181.

Yocum, Thomas (2014): Loba Lingala! An English guide to the language of Kinshasa. Sampson Low Ltd, Kinshasa. 